\title{
APOPTOTIC INDUCTION POTENTIALS OF BACOPA MONERI AGAINST ORAL CANCER CELL LINE
}

\author{
KEERTHANA B ${ }^{1 *}$, GAYATHRI $\mathbf{R}^{2}$, VISHNU PRIYA $\mathbf{V}^{2}$ \\ ${ }^{1}$ Department of Biochemistry, Saveetha Dental College and Hospitals, Saveetha University, Chennai, Tamil Nadu, India. ${ }^{2}$ Department of \\ Biochemistry, Saveetha Dental College and Hospitals, Saveetha University, Chennai, Tamil Nadu, India. Email: keerthana97@yahoo.co.in
}

Received: 30 May 2016, Revised and Accepted: 01 June 2016

\section{ABSTRACT}

Aim: To assess the apoptotic induction potentials of Bacopa monnieri against oral cancer cell.

Objective: This research is done to find the apoptotic induction potentials of B. monnieri against oral cancer cell line.

Background: The apoptosis is a process of programed cell death that occurs in multicellular organisms. Biochemical events lead to characteristic cell changes and death. The initiation of apoptosis is tightly regulated by activation mechanisms, because once apoptosis has begun, it inevitably leads to the death of the cell. The two best-understood activation mechanisms are the intrinsic pathway (also called the mitochondrial pathway) and the extrinsic pathway.

Methods: The apoptotic induction potential of B. monnieri was studied on KB cell line by investigating the activation of caspase 3 and caspase 9.

Reason: Oral cancer is a growing concern due to the changes in lifestyle. The treatment for this disease has been degraded the patient's health by causing various side effects. An effective treatment for the long run is necessary. Usable of herbal plants can serve to be a possible and very effective remedy.

Results: Apoptotic induction potentials of B. monnieri against oral cancer cell line were studied.

Conclusion: Caspase 3 and caspase 9 was activated thus proving the apoptotic potential of B. monnieri.

Keywords: Bacopa monnieri, oral cancer, apoptotic induction.

(C) 2016 The Authors. Published by Innovare Academic Sciences Pvt Ltd. This is an open access article under the CC BY license (http://creativecommons org/licenses/by/4. 0/) D0I: http://dx.doi.org/10.22159/ajpcr.2016.v9i5.13162

\section{INTRODUCTION}

Bacopa monnieri, also known as Brahmi, is a medicinal herb. It has been named as Brahmi as it is related to the brain and it is the center of creative activity. It has also been believed that the word is derived from the word "Brahma" who's the mythical creator in the Hindu philosophy [1]. It is native to the wetlands if Southern India, Europe, Africa, Asia, and North and South America. It has been used in India over long periods of time as an Ayurvedic medicine [2].

Cancer has become one of the rapid diseases in today's world due to changes in our lifestyle. This has caused widespread awareness and concern among the people all over the globe. The major cause of cancer is due to the deregulation of cellular processes and the suppression of apoptotic processes, which leads to the growth of tumor cells and their accumulation [3]

It has also been estimated that there will be a significant increase in the number of cases in the fourth coming years. The treatment options for the disease have been very minimal, and there are researches being done to find the best possible way against cancer using medicinal plants and herbs. This alternative method is used so that the side effects caused are reduced as they are used for a long period of time. It's been found that there are many plants which induce apoptosis to cancer cells. The plant extracts have been proven to have great impacts on the same. p53 is the first tumor suppressor gene which was discovered to be linked to apoptosis. The mutation of this gene is common in almost tumors [4].

Apoptosis which is the programed cell death is characterized by distinct morphological and energy dependent biochemical mechanisms [5]. These changes include condensation of the nucleus and cytoplasm with the preservation of cellular organelles [6]. The defects in apoptosis may lead to a number of human disorders from neurodegenerative disorders to tumors [4]. Apoptosis can take place through the extrinsic or the intrinsic pathway. In the extrinsic pathway, the extracellular ligand so bound to the surface induces changes for the death of the cell. The extrinsic signals are obtained by the coupling of tumor necrosis factor (TNF) receptor. This is been suggested by two models, namely, TNF-induced model and the Fas-Fas model [7]. On the other hand in the intrinsic pathway, the cell death is mediated through mitochondria [8].

In most cases, anticancer therapies are achieved by the activation of caspases which basically belong to the family of cysteine proteases which act as a death effector molecules. Caspases, at first, exist as inactive proteins which are later activated. This activation can be initiated at various places, which include the plasma membrane, or the mitochondria. This leads to the formation of a proteolytic caspase cascade [9]. Caspases can be classified as activators or effectors based on their regulation [10].

\section{METHODS}

\section{Preparation of extract}

The sample for the experiment was obtained by powdering the leaves of B. monnieri on a mortar and grinder with a pestle. This was done three times for obtaining the required amount of the sample.

\section{Maintenance of KB cell line}

Cell flasks were selected and observed under an inverted microscope for cell culturing. The technique of subculture get was performed for the extraction of the cells from the existing medium and then transferring 
Table 1: Caspase-3 activity of Bacopa monnieri extracts using oral cancer cell lines (KB)

\begin{tabular}{|c|c|c|c|c|c|}
\hline \multirow[t]{2}{*}{ Concentration $(\mu \mathrm{g})$} & \multirow[t]{2}{*}{ Control } & \multicolumn{2}{|l|}{ OD value } & \multicolumn{2}{|l|}{$\%$ of caspase activation } \\
\hline & & Caspase 3 & Caspase 9 & $\%$ of caspase 3 activation & $\%$ of caspase 9 activation \\
\hline 50 & 0.5116 & 0.6498 & 0.6159 & 127.0132916 & 120.3870211 \\
\hline 100 & 0.5116 & 0.7458 & 0.7036 & 145.7779515 & 137.5293198 \\
\hline 150 & 0.5116 & 0.8374 & 0.7964 & 163.6825645 & 155.668491 \\
\hline
\end{tabular}

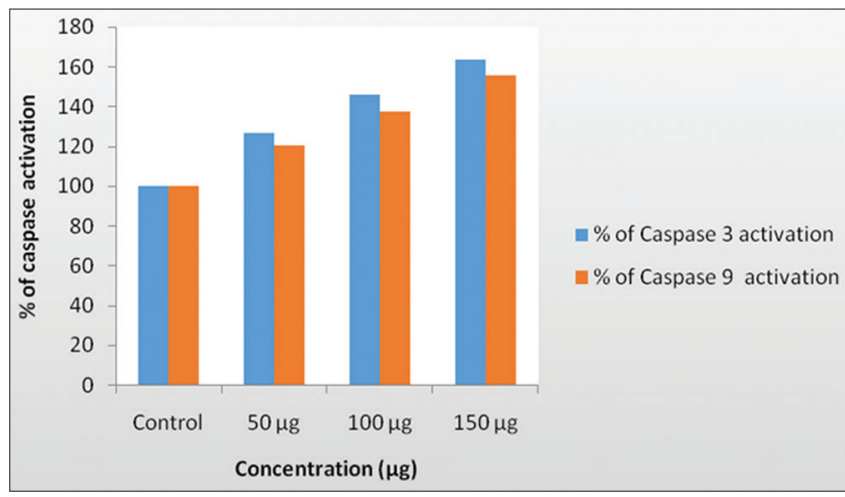

Fig. 1: Caspase-3 activity of Bacopa monnieri extracts using Oral cancer cell lines (KB).

them into a new medium. Enzymatic methods using trypsin phosphate versene glucose was done for the maintenance of the cell. After the addition of the enzymes, the medium was completely drained. The cells were incubated at a temperature of $37^{\circ} \mathrm{C}$ which leads to the detachment of the cells from the surface. The cells, then, were suspended in a $5 \mathrm{ml}$ medium to break from the clumps of cells. This was repeated for 2-3 times. The T-flask was then marked with the seeding date, cell line, and the passage number. This cell suspension was then transferred to a new T-flask.

\section{Determination of caspase activity}

Caspases activities were determined by colorimetric assays using caspase 3 and caspase 9 activation kits according to the manufacturer's protocol. After treated with designated concentrations of extract $(50-150 \mu \mathrm{g} / \mathrm{ml}, 0 \mu \mathrm{g} / \mathrm{ml}$ [control]), cell lysates were prepared by incubating $2 \times 106$ cells $/ \mathrm{ml}$ in cell lysis buffer for 10 minutes on ice. Lysates were centrifuged at $10,000 \times \mathrm{g}$ for 1 minutes. The supernatants (cytosolic extract) were collected, and protein concentration was determined by Bradford's method using bovine serum albumin as a standard. 100-200 $\mu$ g protein (cellular extracts) was diluted in $50 \mu \mathrm{l}$ cell lysis buffer for each assay. Cellular extracts were then incubated in 96 - well microtiter plates with $5 \mu \mathrm{l}$ of the $4 \mathrm{mM}$ p-nitroanilide (pNA) substrates, DEVD-ala-pNA (caspase 3 activity), and Ac-LEHD-pNA (caspase 9 activity) for $2 \mathrm{hrs}$ at $37^{\circ} \mathrm{C}$. Caspase activity was measured by cleavage of the above substrates to free pNA. Free pNA (cleaved substrates) was measured by absorbance at $405 \mathrm{~nm}$ in a microtiter plate reader. Relative caspase 3 activity was calculated as a ratio the absorbance of treated cells to untreated cells.

\section{RESULTS}

It was found that the activity of caspase 3 was greater at the concentrations taken than caspase 9 which is represented in Table 1 and Figure 1.

\section{DISCUSSION}

The use of herbs as drugs against cancer has been found to be very effective with much less or no side effects. The herbs having anticancer property show apoptotic induction potential on tumor cells can therefore be used to treat them. Anticancer activity by apoptotic induction by herbs does not show any side effects. Caspases which belong to proteases induce programmed cell death or apoptosis. The process begins with the activation of the initiator protease, a series of reactions take place which activates several other executioner proteases. This leads to apoptosis by means of intrinsic or extrinsic pathway. The conserved biochemical features of apoptotic cell death are the activation of caspases. Once activated, these destructive proteases proceed to systematically deconstruct the cell to ensure its effective removal without damage to surrounding cells and tissue. In this study, apoptotic induction potentials of caspase 3 and caspase 9 was studied on KB cells with the help of three different concentrations $(50,100,150 \mu \mathrm{g})$ of B. monnieri extract. It was found that the percentage activation of caspase 3 was more than that of caspase 9 .

\section{CONCLUSION}

Anticancer and antioxidant property of certain medicinal herbs can therefore be used to treat trauma over a longer period of time which is always very promising. Phytochemicals present in this herb may have antioxidant property. Therefore, B. monnieri may be used in the treatment of cancer. Further research is required to know the exact mechanism of action of B. monnieri.

\section{REFERENCES}

1. Gohil KA, Patel JA. A review on Bacopa monnieri: Current research and future prospects. Int J Green Pharm 2010;4(1):1-9.

2. Stough C, Singh H, Zangara A. Mechanisms, efficacy, and safety of Bacopa monnieri (Brahmi) for cognitive and brain enhancement. Evid Based Complement Altern Med 2015;2015:Article ID: 717605, 1-2.

3. Hunter AM, LaCasse EC, Korneluk RG. The inhibitors of apoptosis (IAPs) as cancer targets. Apoptosis 2007;12(9):1543-68.

4. Lowe SW, Lin AW. Apoptosis in cancer. Carcinogenesis 2000;21(3):485-95.

5. Elmore S. Apoptosis: A review of programmed cell death. Toxicol Pathol 2007;35(4):495-516.

6. Keefe DM, Brealey J, Goland GJ, Cummins AG. Chemotherapy for cancer causes apoptosis that precedes hypoplasia in crypts of the small intestine in humans. Gut 2000;47(5):632-7.

7. Wajant $\mathrm{H}$. The Fas signaling pathway: More than a paradigm. Science 2002:296(5573):1635-6.

8. Mohan S, Abdul AB, Abdelwahab SI, Al-Zubairi AS, Sukari MA, Abdullah R, et al. Typhonium flagelliforme induces apoptosis in CEMss cells via activation of caspase-9, PARP cleavage and cytochrome c release: Its activation coupled with $\mathrm{G} 0 / \mathrm{G} 1$ phase cell cycle arrest. J Ethnopharmacol 2010;131(3):592-600.

9. Fulda S, Debatin KM. Extrinsic versus intrinsic apoptosis pathways in anticancer chemotherapy. Oncogene 2006;25(1):4798-811.

10. Riedl SJ, Shi1 Y. Molecular mechanisms of caspase regulation during apoptosis. Nat Rev Mol Cell Biol 2004;5(11):897-907. 